\title{
Some ecological factors influencing the breeding success of the Brenton Blue butterfly, Orachrysops niobe (Trimen) (Lepidoptera: Lycaenidae)
}

\author{
D.A. EDGE
}

Edge, D.A. 2002. Some ecological factors influencing the breeding success of the Brenton Blue butterfly, Orachrysops niobe (Trimen) (Lepidoptera: Lycaenidae). Koedoe 45(2): 19-34. Pretoria. ISSN 0075-6458.

The Brenton Blue butterfly, Orachrysops niobe (Trimen, 1862) (Lepidoptera: Lycaenidae), is endemic to the southern Cape and is currently listed as Endangered. This study looks at some of the key ecological factors influencing the breeding success of the species-host plant abundance and condition, nectar sources, climate/ microclimate, and vegetation management techniques. The adult butterfly population was monitored over an entire breeding season; host plants were identified and individually monitored; and egg counts were done. This enabled the effects of a number of different management techniques to be evaluated (burning, cutting, physical removal of invasive elements, and combinations thereof). A fivefold increase in the population of $O$. niobe was observed over the breeding season. This increase was positively correlated to a similar increase in host plant abundance in the areas where cutting and physical removal of invasive elements was practiced. Burning, by contrast, appeared to have a negative impact on host plant and butterfly abundance over the same period. Impacts of other factors such as climate, nectar sources and the natural strength of the second brood are discussed. A hypothesis, of megaherbivore activity as the principal historical disturbance mechanism promoting locally favourable conditions for $O$. niobe to establish and maintain colonies, is proposed. Recommendations for reserve management and future research are made.

Key words: butterfly ecology, endangered species, nectar, population dynamics, population counts, reserve management.

D.A. Edge, School of Environmental Sciences and Development, Potchefstroom University, P O Box 2586, Knysna, 6570, Western Cape Province, South Africa.

\section{Introduction}

The Brenton Blue butterfly Orachrysops niobe (Trimen, 1862) (Lepidoptera: Lycaenidae) is one of South Africa's most threatened butterfly species, being endemic to the southern Cape and currently red-listed as Endangered (Henning \& Henning 1995). It is now only known to occur at one locality —at Brenton-on-Sea near Knysna. It previously occurred in Nature's Valley $50 \mathrm{~km}$ to the east but has become extinct there as a result of anthropogenic activities (property development, habitat fragmentation, prevention of fires, and exclusion of larger herbivores). The colony at Brenton-on-Sea has been subject to similar pressures but has been given a reprieve from a similar fate following a protracted and highly publicised campaign to save the species (Steenkamp \& Stein 1999). This has resulted in the procurement of the land on which the colony occurs by central government and the impending proclamation of a reserve which covers 1.47 ha.

Research has been conducted on the life history (Edge \& Pringle 1996; Williams 1996); butterfly population size and distribution (Britton \& Silberbauer 1997); the ant populations found at the site (Robertson 1997, 1998, 2000); and on the floristics and plant communities (Lubke et al. 1996).

Case histories from other endangered butterfly species (mostly from the northern hemi- 


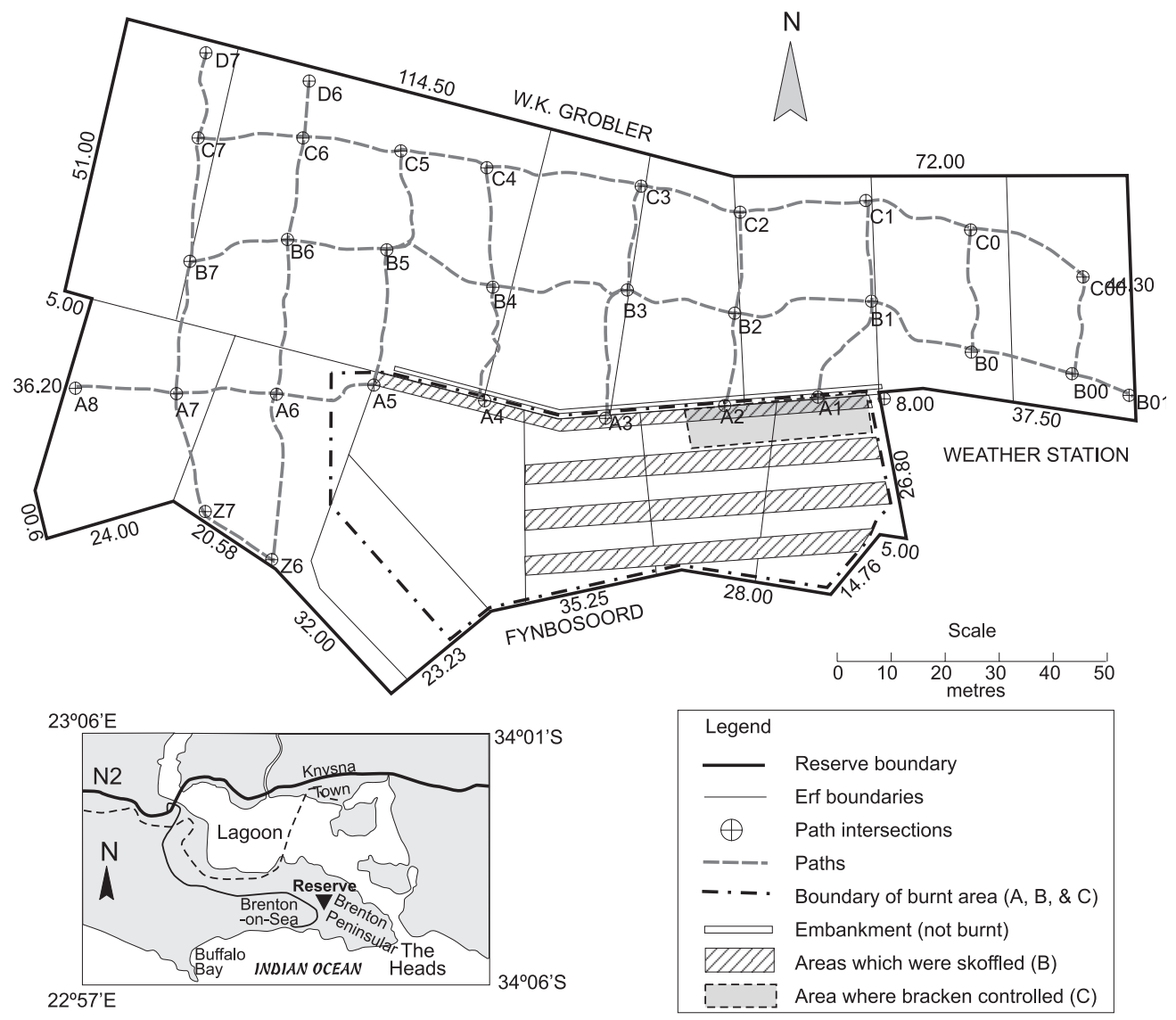

Fig. 1. Brenton Blue Butterfly Reserve, near Knysna.

sphere) have shown that it is essential to understand the ecology of each endangered butterfly species in detail if conservation efforts are to succeed (New 1997).

The aim of the current research is to determine some of the critical ecological factors influencing the breeding success of $O$. niobe. Since Edge \& Pringle (1996) demonstrated by rearing adult $O$. niobe from ova that the larvae are essentially phytophagous the abundance and condition of the sole larval host plant Indigofera erecta Thunberg is one of the factors examined in detail. Several vegetation management techniques to promote proliferation of the host plant have been proposed by other workers (Lubke et al. 1996; Schutte-Vlok 2001), and their efficacy needs to be tested. Other factors dealt with in the present study are nectar sources and preferences; the influence of climate; and the population dynamics of $O$. niobe.

\section{Study site}

The study site is the Brenton Blue butterfly reserve, situated in Brenton-on-Sea near Knysna $\left(34^{\circ} 04^{\prime} 20^{\prime \prime} \mathrm{S} ; 23^{\circ} 02^{\prime} 00^{\prime \prime} \mathrm{E}\right)$ in the Western Cape Province of South Africa (Fig. 1). This figure is to scale and depicts areas that were treated as well as the network of paths that were cut. The reserve has a total area of $14673 \mathrm{~m}^{2}$. 


\begin{tabular}{|c|c|c|}
\hline Treatment & Area $\left(\mathrm{m}^{2}\right)$ & Description of treatment \\
\hline A & 1400 & Burnt on 20 September 2000. Natural succession thereafter. \\
\hline $\mathrm{B}$ & 1000 & $\begin{array}{l}\text { Burnt on } 20 \text { September 2000. "Skoffeled" prior to fire, natural succession } \\
\text { thereafter. }\end{array}$ \\
\hline $\mathrm{C}$ & 300 & $\begin{array}{l}\text { Burnt on } 20 \text { September } 2000 \text {. Bracken fern controlled by manually pulling } \\
\text { new plants out for } 6 \text { months thereafter. }\end{array}$ \\
\hline $\mathrm{D}$ & 1500 & $\begin{array}{l}\text { Network of access paths cut through the unburnt portion of the reserve, and } \\
\text { kept open thereafter. }\end{array}$ \\
\hline $\mathrm{E}$ & 10450 & Undisturbed, unburnt blocks inside paths \\
\hline $\mathrm{F}$ & 120 & $\begin{array}{l}\text { Steep } 1.5 \mathrm{~m} \text { high embankment created by excavation for sewerage line in early } \\
1990 \mathrm{~s}\end{array}$ \\
\hline
\end{tabular}

The reserve is bounded to the north by a tarred road, W.K. Grobler Drive. To the north of this road is a public open space, Uitzicht 216 Portion 81, which is owned by the District Municipality. To the south, the reserve boundary is Fynbosoord, a tarred access road to the residential properties which lie south of Fynbosoord and at the south-eastern corner of the reserve. The reserve is bounded on the west by residential properties and stands, and Mountain Rose Drive. The eastern boundary abuts partly on residential property and partly onto public open space that does not presently form part of the reserve.

The study site is on a well-drained south (seaward) facing slope of average inclination of 1 in 4 . It is at an altitude of $95 \mathrm{~m}$ to $120 \mathrm{~m}$ and is $450 \mathrm{~m}$ from the sea. The geology, climate and floristics of the site were described by Lubke et al. (1996). The vegetation can be characterised as asteraceous coastal fynbos with patches of candlewood-dominated thickets [Pterocelastrus tricuspidatus (Lamont) Sonder].

\section{Materials and methods}

\section{Habitat modification}

Habitat modifications (treatments) were carried out in the areas indicated on the site plan (Fig. 1) and summarised in Table 1 . The procedure for the burn on 20 September 2000 was described by Hiseman (2000). The "skoffeling" treatment applied to Area B involved cutting down of the bracken fern (Pteridium aquilinium (Linnaeus) Kuhn), and turning over the surface layer down to a depth of $0.2 \mathrm{~m}$ so that the roots of the bracken were pulled out. The intention was to simulate the activities of bush pigs, which it had been hypothesised by Schutte-Vlok (2001) played an important role in the past in controlling the bracken fern. The network of access paths (Area D) were cut during the period from 4-25 July 2001, using shears at a level of approximately $10 \mathrm{~cm}$ above the ground, to a width of $1-1.5 \mathrm{~m}$. The paths wind to avoid larger bushes and trees and any patches of the host plant $I$. erecta, and have been subsequently kept open by pulling out any new bracken fern plants. The blocks contained within the paths (Area E) have not been disturbed, but difficulty of access has precluded any systematic host plant observations in this study. Area F consists of a steep embankment approximately $1.5 \mathrm{~m}$ high running east to west which resulted from excavations for a sewerage line in the early 1990 s.

\section{Indigofera erecta monitoring}

Immediately after the fire careful watch was kept for any $I$. erecta seedlings. As soon as they appeared they were marked and identified with 1-m sticks and numbered tags. Thereafter, during host plant surveys, any new plant which had sprouted was similarly identified. These plants were given a letter following the number to show that they were not amongst the original cohort.

When the paths were cut all existing I. erecta plants exposed were also marked, as were the new ones that germinated and/or sprouted later on. No distinction was made as to whether the new plant had originated from seed or had resprouted from an old root stock. 


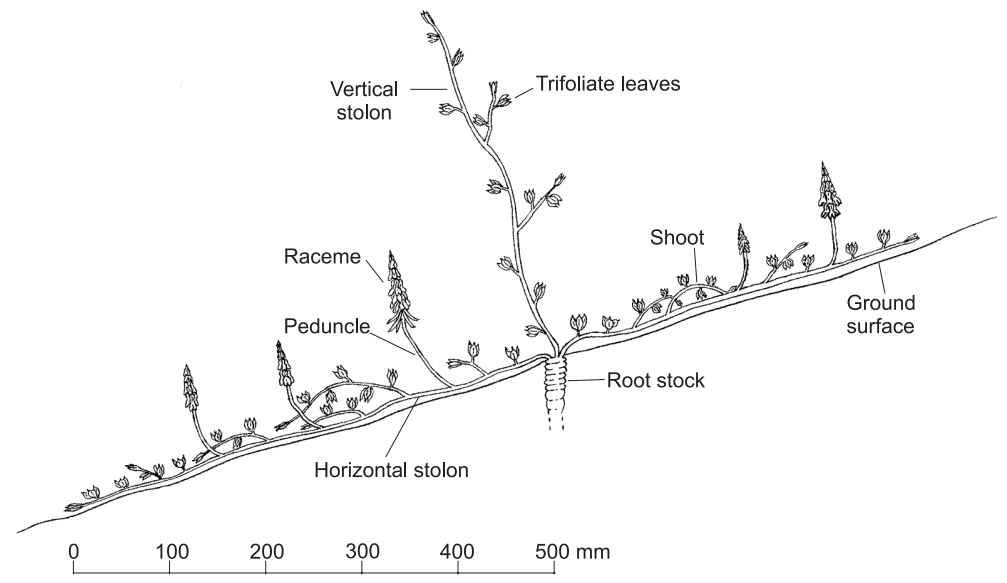

Fig. 2. Typical growth form of Indigofera erecta (diagrammatic).

Surveys of all the identified $I$. erecta plants were conducted at regular intervals (19 March, 9 May, 18 July, 25 July, 10 October, 10-25 November 2001 and 28 January-1 March 2002). During the March and May surveys the health of each plant was recorded. This was a subjective measure made by eye on a scale from 1 to 10 , and took into account the overall size of the plant and its stolons, withering of leaves and stems, and whether the plant appeared to be spreading or shrinking. From July the size of each plant was recorded by counting the number of stolons and the number of inflorescences. A stolon, for the purpose of this study, is defined as an aerial shoot of the plant (horizontal or vertical) which originates near the root stock. Stolons vary in length from $150 \mathrm{~mm}$ to $500 \mathrm{~mm}$. The inflorescences of I. erecta are vertical racemes that carry the flowers on sturdy peduncles. Figure 2 is a diagrammatic sketch of a typical plant (the detailed morphology of the root system is not yet known).

\section{Adult butterfly population counts}

In 2000 and 2001 experiments by the author with mark, release, recapture (MRR) techniques had shown that the trauma to the butterflies caused by this method posed an unacceptable risk to the small and fragile population. Consequently a transect method was devised, using the network of paths, to yield a comparative count of butterflies which could be used to assess population trends. This method required similar weather conditions (sunny, warm, little wind) and was carried out at the same time each day (11:30-12:30). The route through the network was the same for each count, at a fairly constant pace of $20 \mathrm{~m} / \mathrm{min}$., and took about one hour, allowing some time for stops to record significant observations such as nectar plant visitation, oviposition or mating.

During the population counts all adults seen were recorded with the place, gender and activity. Multiple sightings of a particular insect inevitably took place but each sighting was recorded. The observations for each day were recorded on a data sheet that has a schematic layout of the paths in the reserve incorporated and shows the traverse route (Fig. 3).

A second counting method was used which is referred to as the "fixed point" method. The observer was positioned at point $\mathrm{A} 2$ (which is on the normal male patrolling route) and recorded all $O$. niobe that came within 10 metres of this point during a 30 minute period (at the same time each day).

The fixed point method was "calibrated" on several separate occasions by capturing all the butterflies present and retaining them in a gauze netting cage. This enabled a relationship to be derived between the "fixed point" count and the total population of butterflies patrolling (referred to as the repetition factor for this method).

Repetition factor $=$ Total count made $/$ actual butterflies present 


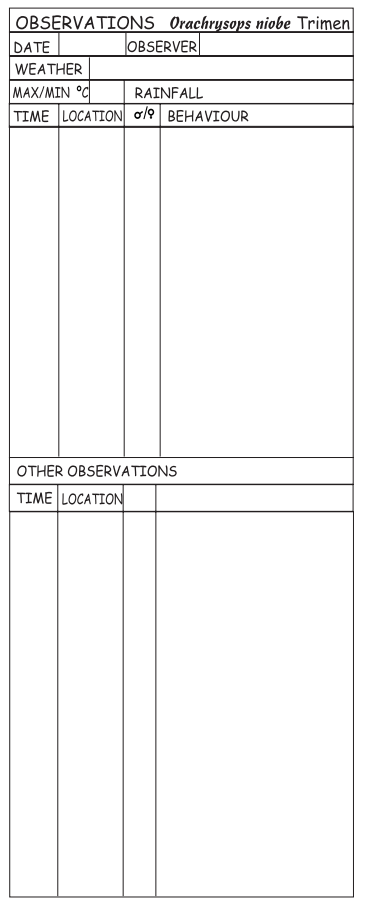

The repetition factor for the transect method could only be estimated (as between 1.25 and 2.0). The butterflies on the paths were much less mobile than the patrolling males mostly seen from the fixed point and the observer moved quickly along each path, reducing the chance of repeat observations of the same insect. Observations made during the transects that fell within the "fixed point" area (defined as the three paths observable from the fixed point A2) were treated as if they were made during a fixed point count for the purpose of applying a repetition factor and calculating the actual butterflies present.

\section{Adult butterfly behaviour}

During the adult butterfly counts and the plant surveys, all noteworthy adult butterfly behaviour was recorded. Categories were defined as fluttering (typical slow female flight within $15 \mathrm{~cm}$ of the ground or vegetation); patrolling (more vigorous male flight up to a metre from the ground or over vegetation); mate search and acquisition (males only); nectar plant visitation (plant species and butterfly gender recorded); host plant search; oviposition (plant number recorded); copulation (time and location recorded); basking, and resting.

\section{Early stages (eggs, larvae)}

All the identified host plants were searched thoroughly during the period from 10-25 November 2001 and again from 28 January-1 March 2002 for eggs and larvae. The search method involved examining both sides of each stolon. In order to standardise the search about one minute was taken to search each stolon. When eggs or larvae were found the host plant number was recorded with the count and any unusual features (e.g., eggs were usually laid on the lower surface of a leaf - so if they were in another position this was recorded). Eggs were recorded as unhatched (pale blue, entire) or hatched (white ring of eggshell remnant).

\section{Climate and microclimate}

Rainfall records from the previous ten years were obtained from a weather station located at 140 Watsonia Road, Brenton-on-Sea. This station is situated at $90 \mathrm{~m}$ altitude, $400 \mathrm{~m}$ from the sea, and $500 \mathrm{~m}$ away from point $\mathrm{A} 1$ in a westerly direction and is also sited on a south-facing slope.

An additional weather station was established at the site (position near A1 as shown on Fig. 1) and daily recordings commenced in June 2001. Data recorded was $\mathrm{mm}$ rainfall using a conical rain gauge and the maximum and minimum temperatures using a thermometer.

The only microclimate factor recorded during the present study was a subjective estimate by eye of the 
Table 2

Plants and stolons of Indigofera erecta counted in each area between March 2001 and February 2002

\begin{tabular}{lcrrrrrc}
\hline \multirow{2}{*}{ Treatment area } & Original & \multicolumn{3}{c}{ Plants per $100 \mathrm{~m}^{2}$} & \multicolumn{3}{c}{ Stolons per $100 \mathrm{~m}^{2}$} \\
& Plants/ & Oct & Nov & Feb & Oct & Nov & Feb \\
& $100 \mathrm{~m}^{2}$ & 2001 & 2001 & 2002 & 2001 & 2001 & 2002 \\
\hline Fire/ bracken control (C) & 16.3 & 16.7 & 19.0 & 14.0 & 32 & 82 & 54 \\
Fire/ no control (A) & 1.7 & 1.9 & 2.0 & 1.9 & 10 & 26 & 13 \\
Embankment (F) & 10.0 & 13.3 & 15.0 & 14.2 & 62 & 128 & 92 \\
Paths in unburnt area (D) & 7.0 & 8.5 & 12.7 & 14.3 & 24 & 109 & 133 \\
\hline TOTALS & 5.7 & 6.6 & 8.9 & 9.0 & 20 & 72 & 73 \\
\hline
\end{tabular}

a Start date for areas (C), (A) and (F) was 19 March 2001, and for area (D) was 25 July 2001.

Table 3

Shade factors, population and growth records of $\mathrm{I}$. erecta in each treatment area

\begin{tabular}{lccccc}
\hline Treatment area & $\begin{array}{c}\text { Shade } \\
\%\end{array}$ & $\begin{array}{c}\text { Original } \\
\text { plants }\end{array}$ & $\begin{array}{c}\text { New } \\
\text { plants }\end{array}$ & Deaths & $\begin{array}{c}\text { Percentage increase in } \\
\text { stolons counted a }^{\text {a }}\end{array}$ \\
\hline Fire/ bracken control (C) & 22.4 & 49 & 17 & 24 & 68 \\
Fire/ no bracken control (A) & 47.6 & 24 & 5 & 3 & 24 \\
Embankment (F) & 81.2 & 12 & 9 & 4 & 49 \\
Paths in unburnt area (D) & 38.3 & 105 & 121 & 12 & 463 \\
\hline Totals/Averages & 38.6 & 190 & 152 & 43 & 265 \\
\hline
\end{tabular}

a Defined as: (Final stolon count - initial stolon count) / (Initial stolon count) x 100

Table 4

Orachrysops niobe total adult population counts between October 2001 and March 2002, using two methods and standardised as counts per hour

\begin{tabular}{lccccc}
\hline \multirow{2}{*}{ Date } & \multicolumn{2}{c}{ First brood } & \multicolumn{3}{c}{ Second brood } \\
\cline { 2 - 6 } & \multicolumn{2}{c}{ Total count $/ \mathrm{h}$} \\
Transects Fixed point & Date & \multicolumn{2}{c}{ Total count/h } \\
Transects & Fixed point \\
\hline 29.10 .01 & 3.81 & 12.0 & 14.01 .02 & 1.60 & \\
08.11 .01 & 4.86 & 13.3 & 28.01 .02 & 19.09 & 42.9 \\
09.11 .01 & 4.55 & & 30.01 .02 & 15.86 & 63.2 \\
10.11 .01 & 4.07 & 12.0 & 04.02 .02 & 18.21 & 35.0 \\
11.11 .01 & 5.41 & 17.1 & 08.02 .02 & 11.79 & 54.0 \\
12.11 .01 & 4.20 & 27.0 & 13.02 .02 & 19.29 & 87.0 \\
13.11 .01 & 3.85 & 10.5 & 17.02 .02 & 13.58 & 39.0 \\
16.11 .01 & 4.76 & 11.4 & 26.02 .02 & 4.14 & 18.0 \\
18.11 .01 & 3.53 & 6.0 & 08.03 .02 & 2.67 & \\
\hline Averages & 4.34 & 13.7 & Averages & 11.8 & 42.9 \\
\hline
\end{tabular}


Table 5

Orachrysops niobe adult population counts for six days at the peak of the November 2001 and February 2002 broods using two counting methods

\begin{tabular}{lcccccc}
\hline Period of Surveys & \multicolumn{3}{c}{$\begin{array}{c}\text { Entire Reserve Transects } \\
(11: 30-12: 30)\end{array}$} & \multicolumn{3}{c}{ Fixed Point A2 } \\
& Males & Females & Totals & Males & Females & Totals \\
\hline November 2001 (1st brood) & 12 & 17 & 29 & 25 & 2 & 27 \\
Jan/Feb 2002 (2nd brood) & 39 & 54 & 93 & 99 & 14 & 113 \\
Ratios (2nd:1st brood) & 3.25 & 3.18 & 3.21 & 3.96 & 7.0 & 4.19 \\
\hline
\end{tabular}

maximum and minimum temperatures using a thermometer.

The only microclimate factor recorded during the present study was a subjective estimate by eye of the extent of shade at each host plant site, ranging from $0 \%$ (no shade for whole day) to $100 \%$ (full shade for whole day).

\section{Results}

\section{Indigofera erecta monitoring}

The number of living $I$. erecta plants located and the number of stolons counted in each treatment area at different dates is given in Table 2, and a summary of the I. erecta microclimate and population dynamics data gathered appears in Table 3.

\section{Adult butterfly population counts}

A summary of the data obtained using the two comparative methods (transect and fixed point) is presented in Table 4. Each day's count using the two methods has been standardised to a count per hour so that the figures for each day are directly comparable. No butterflies were observed between 21 November 2001 and 10 January 2002.

Table 5 presents the total counts from the two methods taken over six days, during the peak emergence of each brood with favourable weather conditions. These results are another assessment of the relative strength of the two broods.

Table 6 presents the results of calculations made from the observations to determine the sex ratio of the adults (assuming a repetition

Table 6

Calculation of O. niobe sex ratios during the November 2001 and February 2002 broods (male and female)

\begin{tabular}{lcccccc}
\hline & \multicolumn{3}{c}{ November 2001 brood } & \multicolumn{3}{c}{ February 2002 brood } \\
Method/area & Transect & Fixed & Total & Transect & Fixed & Total \\
\hline Time (mins) & 740 & 276 & 1016 & 450 & 195 & 645 \\
Male count & 20.5 & 44.5 & 65 & 22.8 & 135.2 & 158 \\
Female count & 25.6 & 7.4 & 33 & 63.3 & 16.7 & 80 \\
Repetition/ hr & 1.25 & 6.56 & & 1.25 & 6.56 & \\
Actual male/h & 1.330 & 1.475 & 2.805 & 2.432 & 6.341 & 8.773 \\
Actual female/h & 1.661 & 0.245 & 1.906 & 6.752 & 0.783 & 7.535 \\
Male:Female ratio & 0.80 & 6.02 & 1.47 & 0.36 & 8.10 & 1.16 \\
\hline
\end{tabular}




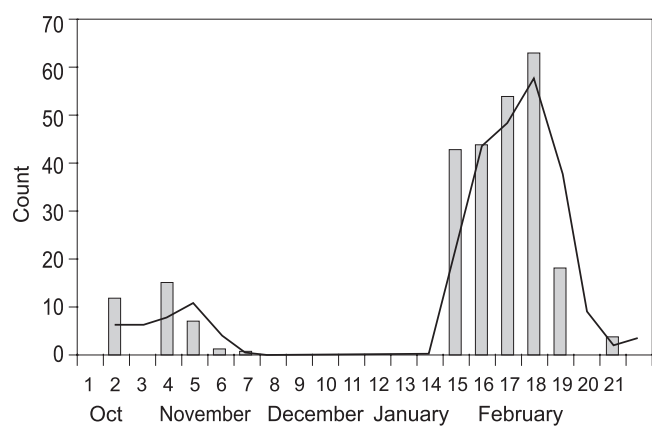

Fig. 4. O. niobe comparative population counts using the fixed point method.

factor of 1.25 for the transect method). The repetition factor for the fixed point method was determined to be 6.6. The overall male to female ratio in the colony falls within the range from 1.2 to 1.5 . If a repetition factor for the transect method of 2.0 is used the male to female ratio falls within the range 1.6 to 1.8 .

Figures 4 and 5 present graphically the population fluctuations over a 21 weeks period from 17 October 2001 to 12 March 2002, using the two methods.

\section{Oviposition}

The $I$. erecta plants preferred for oviposition were mostly healthy and vigorous, on well

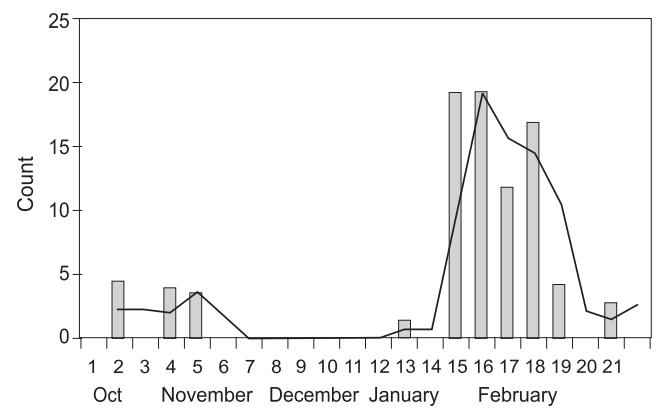

Fig. 5. O. niobe comparative population counts using the transect method. drained sloping ground and in semi shade with bare ground in the immediate vicinity of the plant.

The eggs were usually laid on the underside of leaves on a horizontal stolon close to the ground. The eggs were therefore well concealed and in a cool, damp microclimate. Only occasionally (3.2\% of observations) were eggs laid on the upper surface of the leaves, on stems (as opposed to leaves) or on vertical stolons (as opposed to horizontal stolons). The egg counts $(\mathrm{H}=$ hatched and $\mathrm{U}$ $=$ unhatched) for each brood are presented in Table 7. The data from Tables $7 \& 2$ can be used to calculate egg densities (per plant and per stolon) for each treatment area as shown in Table 8.

Table 7

Orachrysops niobe egg counts in each treatment area during November 2001 and January/February 2002 ( $H=$ hatched eggs and $U=$ unhatched eggs)

\begin{tabular}{|c|c|c|c|c|c|c|c|}
\hline \multirow{3}{*}{ Treatment areas } & \multicolumn{6}{|c|}{ Period of surveys } & \multirow{3}{*}{$\begin{array}{c}\text { Increase } \\
\text { factor } \\
1^{\text {st }-2 \text { nd }} \\
\text { brood }\end{array}$} \\
\hline & \multicolumn{3}{|c|}{10 Nov. 2001 - 25 Nov. 2001} & \multicolumn{3}{|c|}{28 Jan. 2002 - 27 Feb. 2002} & \\
\hline & $\mathrm{H}$ & $\mathrm{U}$ & Totals & $\mathrm{H}$ & $\mathrm{U}$ & Totals & \\
\hline Fire/ bracken control (C) & 2 & 0 & 2 & 15 & 1 & 16 & 8.00 \\
\hline Fire/ no bracken control (A) & 2 & 7 & 9 & 10 & 11 & 21 & 2.33 \\
\hline Embankment $(\mathrm{F})$ & 3 & 1 & 4 & 11 & 2 & 13 & 3.25 \\
\hline Paths in unburnt area (D) & 106 & 109 & 215 & 440 & 606 & 1046 & 4.87 \\
\hline Totals & 113 & 117 & 230 & 476 & 620 & 1096 & 4.76 \\
\hline
\end{tabular}


Table 8

Orachrysops niobe average egg densities per plant and per stolon in each treatment area during November 2001 and January/ February 2002

\begin{tabular}{lcccc}
\hline \multirow{2}{*}{ Areas } & \multicolumn{4}{c}{ Period of surveys } \\
& \multicolumn{1}{c}{ 10 Nov. 2001-25 Nov. 2001 } & 28 Jan. 2002 & -27 Feb. 2002 \\
& Per 100 plants & Per 100 stolons & Per 100 plants & Per 100 stolons \\
\hline Fire/ bracken control (C) & 0.035 & 0.008 & 0.38 & 0.10 \\
Fire/ no bracken control (A) & 0.32 & 0.02 & 0.81 & 0.12 \\
Embankment (F) & 0.22 & 0.026 & 0.77 & 0.12 \\
Paths (D) & 1.13 & 0.13 & 4.89 & 0.53 \\
\hline TOTALS & 0.78 & 0.096 & 3.65 & 0.45 \\
\hline
\end{tabular}

\section{Nectar plant visitation}

A summary of the observations made of $O$. niobe adults visiting nectar plants appears in Table 9. Thirteen angiosperm species were recorded from 10 different families, with
Selago glomerata Thunberg being the most frequently selected nectar source $(35.7 \%$ of observations). Actinomorphic (radially symmetrical) flowers were narrowly preferred over zygomorphic (bilaterally symmetrical) flowers $(53.6 \%)$ and lilac or pale blue flow-

Table 9

Nectar sources and visitations by $\mathrm{O}$ niobe adults

\begin{tabular}{|c|c|c|c|c|c|c|}
\hline Plant species & Family & $\begin{array}{l}\text { Number of } \\
\text { visitations a }\end{array}$ & Months & Areas & $\begin{array}{l}\text { Flower } \\
\text { colour }\end{array}$ & Symmetry $b$ \\
\hline Commelina africana $\mathrm{L}$. & COMMELINACEAE & $2 \mathrm{~F}$ & February & D2 & Yellow & Z \\
\hline Hypoxis villosa $\mathrm{L}$. & HYPOXIDACEAE & $1 \mathrm{~F}$ & November & $\mathrm{C} 1$ & Yellow & A \\
\hline Felicia echinata (Thunb.) & ASTERACEAE & $1 \mathrm{M}$ & February & $\mathrm{C} 1$ & $\begin{array}{l}\text { Lilac \& } \\
\text { yellow }\end{array}$ & A \\
\hline \multirow[t]{2}{*}{ Lobelia tomentosa L. f. } & \multirow[t]{2}{*}{ CAMPANULACEAE } & \multirow[t]{2}{*}{$1 \mathrm{M} ; 3 \mathrm{~F}$} & January & $\mathrm{A} 1 ; \mathrm{C} 2$ & & \\
\hline & & & February & D1 & Blue & $\mathrm{Z}$ \\
\hline Erica speciosa Andrews & ERICACEAE & $2 \mathrm{~F}$ & January & D2 & Red & $\mathrm{A}$ \\
\hline Indigofera erecta Thunb. & FABACEAE & $1 \mathrm{~F}$ & November & D1 & Pink & $\mathrm{Z}$ \\
\hline \multirow{2}{*}{$\begin{array}{l}\text { Indigofera verrucosa } \\
\text { Eckl.\& Zeyh. }\end{array}$} & \multirow[t]{2}{*}{ FABACEAE } & \multirow[t]{2}{*}{$2 \mathrm{M} ; 3 \mathrm{~F}$} & January & & & \\
\hline & & & February & $\mathrm{C} 5$ & Pink & $\mathrm{Z}$ \\
\hline Rhynchosia caribea (Jacq.) & FABACEAE & $1 \mathrm{M}$ & February & $\mathrm{C} 1$ & Yellow & $\mathrm{Z}$ \\
\hline $\begin{array}{l}\text { Rhynchosia chrysoscias } \\
\text { Benth. ex Harv. }\end{array}$ & FABACEAE & $6 \mathrm{M} ; 6 \mathrm{~F}$ & November - & $\mathrm{C} 8$ & & \\
\hline \multirow{2}{*}{ Geranium incanum Burm. } & \multirow{2}{*}{ GERANIACEAE } & \multirow{2}{*}{$3 \mathrm{M} ; 2 \mathrm{~F}$} & \multirow{2}{*}{ November } & $\begin{array}{l}\text { D4 } \\
\text { C4 }\end{array}$ & Yellow & Z \\
\hline & & & & A1 & Lilac & A \\
\hline $\begin{array}{l}\text { Sebaea aurea (L.f.) Roem. } \\
\text { \& Schult. } \\
\text { Polygala fruticosa }\end{array}$ & GENTIANACEAE & $1 \mathrm{M}$ & November & A1 & Yellow & A \\
\hline \multirow{3}{*}{$\begin{array}{l}\text { Polygala fruticosa } \\
\text { P.J.Bergius } \\
\text { Selago glomerata Thunb. }\end{array}$} & \multirow{3}{*}{$\begin{array}{l}\text { POLYGALACEAE } \\
\text { SELAGINACEAE }\end{array}$} & \multirow{3}{*}{$\begin{array}{c}1 \mathrm{~F} \\
8 \mathrm{M} ; 12 \mathrm{~F}\end{array}$} & February & D1 & Purple & $\mathrm{Z}$ \\
\hline & & & January & C15 A & & \\
\hline & & & February & $3 \mathrm{D} 2$ & Pale blue & A \\
\hline Totals & 10 Families & $\begin{array}{l}23 \mathrm{M} \\
33 \mathrm{~F}\end{array}$ & & $\begin{array}{l}\text { A6 C } 37 \\
\text { D13 }\end{array}$ & & \\
\hline
\end{tabular}

a $\mathrm{M}=$ male and $\mathrm{F}=$ female

$\mathrm{b} \mathrm{A}=$ actinomorphic and $\mathrm{Z}=$ zygomorphic 
ers were chosen over other colours (57.1\%). The majority of the nectar plant visitation observations were made in the burnt areas (76.8\%), where the preferred nectar plants (which were mostly forbs) were more abundant.

\section{Climate}

The weather data in Table 10 was obtained from the 140 Watsonia Road weather station (rainfall); the weather station at the reserve (rainfall and temperatures); and the Knysna records of S.A. Weather Services (SAWS). The Watsonia Road and reserve stations agreed for rainfall records over fourteen months to within $1.5 \%$. There is also good agreement between the Watsonia Road station and SAWS over the longer term.
Overall comparison of the burnt areas versus the paths

Drawing the data together from the various sources in this study the summary compiled in Table 11 was produced.

\section{Discussion}

Reproduction and growth of Indigofera erecta

The genus Indigofera is large, with 78 species occurring in the Cape Floristic Region (CFR) and 720-730 worldwide (Goldblatt \& Manning 2000). The taxonomy is still being actively researched and Goldblatt \& Manning identify 19 undescribed species in the CFR (24\% of the total). A variety of reproductive strategies are evident in the genus,

Table 10

Weather records for the Knysna area

\begin{tabular}{|c|c|c|c|c|c|c|c|c|c|}
\hline \multirow[t]{2}{*}{ Month } & \multicolumn{3}{|c|}{$\begin{array}{l}140 \text { Watsonia Road } \\
\text { rainfall }(\mathrm{mm})^{\mathrm{a}}\end{array}$} & \multicolumn{3}{|c|}{$\begin{array}{c}\text { Brenton Blue } \\
\text { butterfly reserve }\end{array}$} & \multicolumn{3}{|c|}{$\begin{array}{l}\text { Knysna - S.A. } \\
\text { Weather Service }^{c}\end{array}$} \\
\hline & Max. & Min. & Mean & $\begin{array}{c}\text { Rainfall } \\
\text { mean } \\
\text { mm }\end{array}$ & $\begin{array}{c}\text { Average } \\
\max . \\
{ }^{\circ} \mathrm{C}\end{array}$ & $\begin{array}{c}\text { Average } \\
\text { min } \\
{ }^{\circ} \mathrm{C}\end{array}$ & $\begin{array}{c}\text { Rainfall } \\
\text { mean } \\
\text { mm }\end{array}$ & $\begin{array}{c}\text { Average } \\
\max . \\
{ }^{\circ} \mathrm{C}\end{array}$ & $\begin{array}{c}\text { Average } \\
\text { min } \\
{ }^{\circ} \mathrm{C}\end{array}$ \\
\hline January & 82 & 21 & 52.4 & 53 & 28.6 & 14.5 & 56.8 & 26.2 & 17.1 \\
\hline February & 85 & 12 & 47.3 & 16 & 28.4 & 14.9 & 47.9 & 27.2 & 16.7 \\
\hline March & 107 & 6 & 57.0 & 14 & 26.8 & 15.5 & 59.7 & 27.1 & 17.0 \\
\hline April & 122 & 0 & 60.8 & 37 & 24.8 & 13.2 & 65.7 & 20.1 & 10.1 \\
\hline May & 128 & 6 & 51.3 & 62 & 20.4 & 10.7 & 64.7 & 21.4 & 11.4 \\
\hline June & 74 & 8 & 34.3 & 44 & 17.4 & 8.4 & 64.0 & 19.5 & 8.3 \\
\hline July & 117 & 18 & 61.0 & 62 & 17.5 & 9.0 & 60.9 & 19.0 & 8.7 \\
\hline August & 200 & 0 & 85.2 & 103 & 20.5 & 9.9 & 84.6 & 20.1 & 10.0 \\
\hline September & 216 & 35 & 61.7 & 54 & 19.9 & 10.9 & 64.7 & 20.9 & 11.9 \\
\hline October & 192 & 25 & 87.4 & 42 & 22.8 & 13.5 & 74.2 & 22.9 & 14.7 \\
\hline November & 122 & 0 & 87.3 & 85 & 24.9 & 13.8 & 59.0 & 23.3 & 15.9 \\
\hline December & 144 & 12 & 62.5 & 53 & 27.8 & 15.1 & 50.8 & 24.9 & 17.1 \\
\hline Annual & 1078 & 564 & 756.3 & 625 & & & 753.1 & & \\
\hline
\end{tabular}

a from January 1992 to August 2002

b from July 2001 to August 2002

c from January 1951 to August 2002 
Summary of data comparing the burnt areas with the paths

\begin{tabular}{lcc}
\hline Description of data & $\begin{array}{c}\text { Burnt areas } \\
\text { A, B \&C }\end{array}$ & $\begin{array}{c}\text { Paths } \\
\text { (Area D) }\end{array}$ \\
\hline Total area $\left(\mathrm{m}^{2}\right)$ & 2700 & 1500 \\
Final $I$. erecta stolons count & 341 & 1988 \\
Final $I$. erecta stolons per $100 \mathrm{~m}^{2}$ & 13 & 130 \\
I. erecta stolon increase (\%) & 41.5 & 463 \\
O. niobe eggs laid per $100 \mathrm{~m}^{2}$ (November) & 0.4 & 14.3 \\
O. niobe eggs laid per $100 \mathrm{~m}^{2}$ (February) & 1.3 & 70 \\
O. niobe eggs laid per plant (November) & 0.129 & 1.13 \\
O. niobe eggs laid per plant (February) & 0.544 & 4.89 \\
\% of total $O$. niobe eggs laid (November) & 6.5 & 93.5 \\
\% of total $O$. niobe eggs laid (February) & 4.6 & 95.4 \\
\% of male $O$. niobe sightings (November) & 69.0 & 31.0 \\
\% of female $O$. niobe sightings (November) & 22.2 & 77.8 \\
\% of male $O$. niobe sightings (February) & 31.1 & 68.9 \\
\% of female $O$. niobe sightings (February) & 10.6 & 89.4 \\
Adult $O$. niobe nectar visitations & 43 & 13 \\
Average shading factor (\%) & 43 & 38 \\
\hline
\end{tabular}

with six species being described as resprouting and six as reseeding shrubs or shrublets. The biology and phenology of $I$. erecta have not yet been studied as far as can be ascertained. Two other Indigofera species have been identified at the site (I. verrucosa and I. glaucescens Ecklon \& Zeyher).

Schutte-Vlok (2001) hypothesised that the germination of $I$. erecta was principally fire induced, and used this as one of the main arguments for management of the reserve by regular controlled burns. Jeffrey et al. (1997) found that not all legume species tested germinated in response to dry heat treatment and hypothesised that species found in dune or forest communities, which were less fire prone, required other stimuli to break seed dormancy. Cocks \& Stock (1997), in a study of germination stimulation of 16 Fabaceae species, found that response to fire varied and seemed to be correlated with certain seed characteristics.

Observations and experimentation on the host plant of Orachrysops ariadne (Butler, 1898) - which is Indigofera woodii H.Bolus var. laxa - indicated that whilst fire and heat seemed to play a role in seed germination, seedlings emerged in unburned areas as well as burnt areas. (Lu \& Samways 2002b).

The evidence accumulated in the present study indicates that the germination of $I$. erecta is stimulated not only by fire as expected (Table 3-areas A and C-" new plant" column) but also by surface disturbance and by removal of competing plants to admit more light (access paths - area D). Effects similar to this could have been caused naturally in the past by megaherbivores creating paths for access and passage, and by their browsing and grazing on the plants along the paths. Elephants may have occasionally visited the area in the past and their partiality to many typical fynbos plants as well as $P$. tricuspidatus, and the rhizomes of $P$. aquilinium has been recorded recently in fynbos areas adjacent to the Knysna forest (Milewski 2002). It is interesting that these two species have a tendency to proliferate at the study site in the absence of any control agent(s).

At the study site the predominant growth form of $I$. erecta is depicted diagrammatically in Fig. 2. Most of the vegetative mass is contained in the horizontal stolons, which are 
up to $500 \mathrm{~mm}$ long and spread along the ground in a horizontal or downward direction, depending on the slope of the ground. Vertical stolons are much less frequent and appear to be a response to there being greater ground cover by competing plants in the vicinity. Since the stems of $I$. erecta are herbaceous the height of the vertical stolons is limited to $100 \mathrm{~mm}$ by their mechanical strength unless support is gained from neighbouring plants, in which case a height of a metre or more can be attained. Leaves are sparser on these vertical stolons compared to the horizontal stolons, which are supported by the ground and therefore able to bear many more leaves.

The growth form described above is markedly different from the host plant of $O$. ariadne which is an upright plant growing to over a metre and which has woody stems ( $\mathrm{Lu} \&$ Samways 2001). This type of growth form can compete successfully with taller plants and does not require bare ground to grow vigorously which appears to be the case with $I$. erecta.

The influence of growth form can be seen by comparing the response of $I$. erecta to fire as opposed to cutting and clearing around the plant. The $I$. erecta plants that sprouted after the fire did well at first, while the ground was bare and there was not much shade. However they were out-competed later as the ground became covered with grass and sedge species and the taller more vigorous species (P. aquilinium, Helichrysum spp, Rhyncosia $\mathrm{spp}$, etc) shaded out the smaller $I$. erecta plants. Consequently growth of both horizontal and vertical stolons was inhibited and not only did a high proportion of $I$. erecta plants die during the observation period (refer to Table 3), but also the overall increase in the number of stolons was low.

By contrast the $I$. erecta plants which were present on the paths, together with those that sprouted subsequently, had a much lower mortality and a far greater rate of increase in the number of stolons (refer to Tables $2 \& 3$ ). This shows clearly that growth of $I$. erecta was encouraged to a far greater extent by the activity (disturbance) of cutting the access paths rather than by the fire.

It is noteworthy that parts of the reserve area were regularly disturbed in the 1980s and early 1990s by the property owner - who used to cut down the taller plants every few years to gain access for surveying. Escom also used to keep the strip of ground along their power servitude just below the present W. K. Grobler Drive open for maintenance access. These sort of activities may have been critical sustaining factors for the butterfly at the site over the last two decades.

\section{Orachrysops niobe adult population fluctu-}

ations

The author has been keeping records of adult population counts dating back to 1993. In that year, using a method similar to but not as rigorous as in the present study, a maximum count of $10 / \mathrm{h}$ was obtained for the November brood using a fixed point observation method. In November 2000 the maximum count was $16 / \mathrm{h}$ also using a fixed point method, and in November 2001 the maximum count was $15 / \mathrm{h}$. It can therefore be stated with reasonable confidence that the November population of adult $O$. niobe has not shown any significant decline over the eight year period, and if anything seems to have increased.

However, in previous years, whilst the author has sparse records for December, January and February, a major second brood such as emerged in February 2002 has never been detected, with at most a hand full of individuals being seen. The three to four fold increase in the adult numbers between November 2001and February 2002 (Figs. 4 $\& 5)$, and the nearly five fold increase in the egg counts between the two broods, show that $O$. niobe is strongly bivoltine if favourable conditions exist, with early and late summer emergences. This contrasts greatly with $O$. ariadne which is univoltine and only emerges in autumn (April/May). (Lu \& Samways 2001) 
There are undoubtedly many other factors which control the population of $O$. niobe, such as predation and parasitism in the larval stage; the influence of the larval-ant relationship and the availability of sufficient ant colonies in proximity to the host plant concentrations. These factors are beyond the scope of the present study but will be the focus of future investigations.

\section{Oviposition preferences of $\boldsymbol{O}$. niobe}

All members of the genus Orachrysops so far studied in any detail appear to specialise on a single larval host plant in the genus Indigofera (refer to Table 12).

In the case of the four colonies of $O$. ariadne studied by Lu \& Samways (2001, 2002a) they found that an abundance of the host plant was an essential pre-condition for a colony to become established and to be maintained.

The abundance of $I$. erecta at the Brenton Blue butterfly reserve is greater than at any other place on the Brenton peninsular, and indeed greater than all other sites investigated for the presence of $O$. niobe over a number of years. (Ball 1997)

An earlier study of oviposition sites found that the host plant and egg densities varied across the reserve (Britton \& Silberbauer 1997), but were generally positively correlated. A similarly patchy distribution of host plant has been found in the present study, with the females concentrating their oviposition activities in areas containing the most host plant.
In the present study, both in the November and February broods the majority of the eggs were laid on the host plants growing on the paths, and the density of eggs per plant and per stolon were also much higher on these host plants.

The preference of the females of $O$. niobe for oviposition on host plants on or near the paths as opposed to plants in the burnt areas could have the following possible causes:

- The very high density of host plant in some areas of the paths attracted the females by sight and smell.

- Predominance on the paths of horizontal stolons close to the ground which are preferred by the females.

- Accessibility of the host plants on the paths - no need to flutter between other plants.

- Health and vigour of the host plants on the paths (see Table 3).

- More favourable microclimate for larval survival may exist along the paths (sheltered, cool and humid).

- Presence of an (as yet unknown) host ant in these areas.

It was concluded from a study of the habitat of the endangered Lycaenid Aloeides dentatis dentatis (Swierstra, 1909) that this butterfly had a preference for a disturbed community in an early stage of succession, which seemed to encourage colonisation by the host ant. (Deutschländer \& Bredenkamp 1999).

Several observations were made during the present study of oviposition by another poly-

Table 12

Larval host plants of Orachrysops species

\begin{tabular}{|c|c|c|}
\hline Species & Host plant & Reference \\
\hline O. lacrimosa (Bethune-Baker, 1923) & Indigofera species unknown & Clark \& Dickson 1971 \\
\hline O. mijburghi Henning \& Henning, 1994 & Indigofera species unknown & Williams 1996 \\
\hline O. niobe (Trimen) & I. erecta Thunberg & Edge \& Pringle 1996 \\
\hline O. brinkmani Heath, 1997 & I. declinata E.Meyer & Heath 1997 \\
\hline O. ariadne (Butler) & I. woodii var. laxa H. Bolus & Lu \& Samways 2001 \\
\hline O. subravus Henning \& Henning, 1994 & I. woodii var. woodii $\mathrm{H}$. Bolus & Lu \& Samways 2001 \\
\hline
\end{tabular}


ommatine Lycaenid Lampides boeticus (Linnaeus, 1767) on the reserve and in all cases this was on the host plant Rhynchosia chrysoscias Bentham ex Harvey, particularly in the burnt area where this climbing shrublet thrives. The niche differentiation between these two closely related butterfly species is clear and reduces potentially harmful larval competition.

\section{Nectar sources}

Nectar sources were hypothesised to be a limiting factor for maintaining colonies of $O$. ariadne in Natal where only eight nectar plants were identified, with an overwhelming preference for two of them. (Lu \& Samways 2001). The wider variety of flowers used by $O$. niobe (13 species) and their relative abundance at the study site leads one to surmise that this is not currently a limiting factor for the population. Furthermore the wide choice of flowers of different symmetry, morphology, size and colour indicates that $O$. niobe is a generalist which does not fulfil any pollination function and is thus a nectar thief.

The dominance of forbs and thus nectar plant visitations in the burnt area is probably because the woodier shrubs had not yet gained ascendancy in the succession process.

\section{Influence of climate and microclimate}

From Table 10 it can be seen that rainfall was well below the average for previous years during the period from October 2001 to March 2002, which is the emergence time for adult $O$. niobe. The increase in butterfly population that has been recorded in this study took place despite the adverse dry and hot conditions. It should be noted that moisture appears to be a critical factor in all Orachrysops species studied so far (Pringle 1997; Lu \& Samways 2001)

From a microclimate point of view, the shade factor and the angle of slope are two of the most important factors. It can be seen from Table 3 that the butterfly larval host plant does better in intermediate shade (approx. $40 \%$ ) situations. Generally the area where the paths were cut had a steeper slope than the burnt area and this made for a cooler microclimate as well as good drainage.

\section{Overall comparison of burning versus cut- ting}

The summary in Table 11 clearly demonstrates that the cut access paths created a superior habitat for both $I$. erecta to grow and for $O$. niobe to breed. The burnt area did however provide more male $O$. niobe activity, principally because it included the current patrolling path of the males. Another important attraction and contribution of the burnt area was as a nectar source because of the prevalence of nectar rich forbs in the early successional stages after a fire. This may have some significance in the overall ecology of the butterfly and needs to be taken into account.

\section{Conclusions}

The germination of the host plant Indigofera erecta is not just fire induced. There was a doubling of the number of host plants on the access paths (area D), where no fire had taken place, during the observation period. Indigofera erecta plants in the burnt areas A and $\mathrm{C}$, and on the embankment (area F) had a higher mortality rate than those on the paths. The growth rate of the plants on the paths - measured by increase in the number of stolons - was an order of magnitude higher than in the burnt area.

Orachrysops niobe females had an overwhelming preference to lay eggs on the I erecta plants on or near the access paths and almost completely avoided the plants on the burnt area. There was a significant increase in the population of the butterfly between the first brood and the second brood - three to four times as many adults, and nearly five times as many eggs laid. Orachrysops niobe uses a wide range of nectar sources, most of which are abundant at the reserve and not likely to be a limiting 
factor in controlling the population, although the higher abundance of nectar sources in the burnt area may have some significance.

The rainfall during this season has been significantly below the historical average so this factor could not have caused the population increase. The evidence suggests rather that both the proliferation of the host plant on the access paths and the increase in the butterfly population came about as a result of the access path cutting and maintenance activities. The areas that were burnt have produced relatively small numbers of $I$ erecta plants on which hardly any eggs were laid. Under natural conditions the type of disturbance caused by the cutting of paths is similar to that created by large and small herbivores grazing. Burning is likely to cause a short-term negative impact on butterfly populations since it not only does not create conditions suitable for breeding, but the danger exists of larvae perishing in any fire occurring during the months from October to April.

\section{Recommendations}

Burning should only be carried out at the reserve in areas where the host plant is absent.

The network of paths should be maintained and kept open through the next breeding season in order to continue monitoring of the host plant and to re-assess the butterfly population in November 2002.

The morphology, reproductive biology (specifically the germination stimuli) and phenology of Indigofera erecta should be studied in detail.

The existence of a larval-ant association needs to be confirmed and investigated to find out if this could be a regulating factor on the populations of the butterfly.

\section{Acknowledgements}

My thanks are due to Cape Nature Conservation for permission to work within the Brenton Blue butter- fly reserve, and to Rhett Hiseman in particular for loan of a GPS instrument belonging to Cape Nature Conservation. Professor Brian Allanson is also thanked for his advice on methods to be used and for the use of laboratory equipment belonging to the Knysna Basin project. I am also grateful to Renier Terblanche, Dr Hamish Robertson and Ernest Pringle for their guidance on methods, data analysis, review of drafts and general discussion and encouragement. Wiehan Properties' role in making available their records from a weather station at Brentonon-Sea and Brian Young's assistance in gathering and compiling of data from the weather station at the Brenton Blue butterfly reserve are also gratefully acknowledged.

\section{References}

BALL, J.B. 1997. Some notes on the Brenton Blue butterfly, Orachrysops niobe (Trimen) (Lepidoptera, Lycaenidae). Unpubl. research report for the Endangered Wildlife Trust of Southern Africa, Johannesburg - Attachment 1: 22-27.

Cocks, M.P. \& W.D STOCK. 1997. Heat stimulated germination in relation to seed characteristics in fynbos legumes of the Western Cape Province, South Africa. South African Journal of Botany 63(3): 129-132.

Britton, D.R. \& L.X. Silberbauer. 1997. The lifehistory, ecology and conservation of the Brenton Blue Butterfly, Orachrysops niobe (Trimen) (Lycaenidae) at Brenton-on-Sea. Unpubl. research report for the Endangered Wildlife Trust of Southern Africa, Johannesburg.

Clark, G.C. \& C.G.C. Dickson. 1971. Life histories of the South African Lycaenid butterflies. Cape Town: Purnell.

DeutsChläNDER, M.S. \& G.J. BREDENKAMP. 1999. Importance of vegetation analysis in the conservation management of the endangered butterfly Aloeides dentatis dentatis (Swierstra) (Lepidoptera, Lycaenidae). Koedoe 42(2): 1-12.

Edge, D.A. \& E.L. Pringle. 1996. Notes on the natural history of the Brenton Blue Orachrysops niobe (Trimen) (Lepidoptera: Lycaenidae). Metamorphosis 7(3): 109-20.

Goldblatt, P. \& J. Manning. 2000. Cape Plants: A conspectus of the Cape flora of South Africa. Pp. 486-492. In: Strelitzia 9. Cape Town: National Botanical Institute of S A \& Missouri Botanical Garden.

Heath, A. 1997. Description of a new species of Orachrysops Vari from the Western Cape Province of South Africa (Lepidoptera: Lycaenidae). Metamorphosis 8(1): 26-32. 
Henning, G.A. \& S.F. Henning. 1995. Updating the status of South African red data butterfly species. Metamorphosis 6(2): 96-98.

Hiseman, R.E. 2000. Brenton Blue Butterfly Reserve management report. Internal report for Cape Nature Conservation (unpublished, dated 30 November 2000).

Jefrerey, D.J., P.M. Holmes \& A.G. Rebelo. 1988. Effects of dry heat on seed germination in selected indigenous and alien legume species in South Africa. South African Journal of Botany 54(1): 28-34.

Lu, S-S. \& M.J. Samways. 2001. Life history of the threatened Karkloof blue butterfly, Orachrysops ariadne (Lepidoptera: Lycaenidae). African Entomology 9(2): 137-151.

Lu, S-S. \& M.J. SAmwAYs. 2002a. Behavioural ecology of the Karkloof blue butterfly, Orachrysops ariadne (Lepidoptera: Lycaenidae) relevant to its conservation. African Entomology 10(1): 137-147.

Lu, S-S. \& M.J. SAmwaYs. 2002b. Conservation management recommendations for the Karkloof blue butterfly, Orachrysops ariadne (Lepidoptera: Lycaenidae). African Entomology 10(1): 149-159.

LubKe, R.A., D.B. HoARE \& J.E. Victor. 1996. The vegetation and floristics of the habitat of the Brenton Blue butterfly. Unpubl. research report for the Endangered Wildlife Trust of Southern Africa, Johannesburg.

MilewSKI, A.V. 2002. Elephants and fynbos. Veld \& Flora March 2002: 28.

New, T.R. 1997. Butterfly Conservation. Melbourne: Oxford University Press.
Pringle, E.L. 1997. Butterfly breeding areas-a microclimate perspective. Metamophosis 8(2): 82-84.

RoBerTSON, H.G. 1997. Report on the ants at Brenton-on-Sea and their possible interactions with the Brenton Blue Butterfly, Orachrysops niobe. Unpubl. research report for the Endangered Wildlife Trust of Southern Africa, Johannesburg.

RoBERTSON, H.G. 1998. Report on field trip to Brenton-on-Sea from 15-26 November 1998. Internal report for Life Sciences Division, South African Museum, Cape Town (unpublished).

ROBERTSON, H.G. 2000. Report on field trip to Brenton-on-Sea from 6-10 November 2000. Internal report for Life Sciences Division, South African Museum, Cape Town.

SCHUTte-VloK, A.L. 2001. Environmental management plan for the Brenton Blue Butterfly Reserve. Internal report for Cape Nature Conservation (unpublished).

SteenKamp, C. \& R. Stein. 1999. The Brenton Blue saga - a case study of South African biodiversity conservation. Johannesburg: Endangered Wildlife Trust/Nedbank/Danish co-operation for Environment and Development.

TRIMEN, R. 1862-1864. On some new species of South African butterflies. Transactions of the Entomological Society, London, 3rd Series Vol I: 279-291.

WiLLIAMS, M.C. 1996. Report on research findings concerning the Life History and Ecology of the Brenton Blue (Orachrysops niobe). Metamorphosis 7(1): 3-7. 